\title{
A SPATIAL DECISION SUPPORT SYSTEM FOR ECOTOURISM DEVELOPMENT IN CASPIAN HYRCANIAN MIXED FORESTS ECOREGION
}

Sistema de suporte a decisão espacial para o desenvolvimento de ecoturismo em regiões de florestas mistas caspian hyrcanian

\author{
ALI BALI ${ }^{1}$ \\ SEYED MASOUD MONAVARI ${ }^{1}$ \\ BORHAN RIAZI ${ }^{1}$ \\ NEMATOLLAH KHORASANI ${ }^{1}$ \\ MIR MASOUD KHEIRKHAH ZARKESH ${ }^{1}$
}

${ }^{1}$ Department of the Environmental Science

Faculty of the Environment and Energy

Tehran Science and Research Branch

Islamic Azad University - Tehran - Iran

Email:monavarism@yahoo.com;

\begin{abstract}
:
Ecotourism, as a form of sustainable nature-based tourism, promotes conservation of ecological and scenic values. In this study, a Spatial Decision Support System, SDSS, was developed based upon Multi Criteria Evaluation, MCE, for ecotourism development in the Caspian Hyrcanian Mixed Forests ecoregion, northern Iran. For this, important criteria and constraints for ecotourism development were shortlisted using the Delphi Method. The criteria were weighted using Analytical Hierarchy Process, AHP. The obtained results indicated that "distance from water resources", "land use", "slope", "soil", "climate", "distance from roads", "land cover density", "erosion", and "distance from residential areas" were the most important criteria, respectively. The findings suggest that GIS-based SDSS is suitable to engage the various criteria affecting the development of ecotourism destinations. This empirical research develops a new method that can significantly facilitate planning forecotourism development with respect to ecological capability of ecotourism destinations.
\end{abstract}

Keywords: Ecotourism; GIS; Decision Support System; AHP; Anzali Watershed. 


\section{Resumo:}

Ecoturismo, como forma de turismo sustentável baseado na natureza promove conservação de valores ecológicos e cênicos. Neste estudo, o Sistema Espacial de Suporte a Decisões, SDSS, foi desenvolvido com base na Avaliação Multi-Critério, MCE, para o desenvolvimento de ecoturismo na ecoregião de florestas mistas caspian hyrcanian, no norte do Irã. Para isto, critérios importantes e restrições para o desenvolvimento do ecoturismo foram listados usando o Método Delphi. Os critérios foram analisados ponderadamente usando o Processo de Hierarquia Analítica, AHP. Os resultados obtidos indicaram que: "distância de fontes de água", "uso da terra", inclinação do terreno", "solo", "clima", "distância das estradas", "densidade de cobertura vegetal", "erosão", e "distância de áreas residenciais", foram os critérios, respectivamente, mais importantes. Os resultados sugerem que o SIG baseado no SDSS é adequado para engajar-se a vários critérios afetando o desenvolvimento dos destinos do ecoturismo. Esta pesquisa empírica desenvolve um novo método que pode facilitar o planejamento para o desenvolvimento do ecoturismo que diz respeito à capacidade ecológica dos destinos ecoturísticos.

Palavras-chave: Ecoturismo; GIS; Sistema de Suporte de Decisão; AHP; Bacia Hidrográfica Anzali.

\section{INTRODUCTION}

The ecotourism term was initially used to describe nature-based traveling for research, and recreational purposes, with special emphasis on conservation of ecological values (CeballosLascurain, 1996; Culbertson et al., 1994). Ecotourism is composed of two words "eco" and "tourism" (Anomasiri, 2004). The concept promotes conservation of ecological and scenic values of tourist destinations (Boyd and Butler, 1993; Lindberg and Mckercher, 1997). In other words, ecotourism must provide a balance between traveling in the nature and conservation of ecosystem values (Dhammapitaka and Payuto, 2000; Weaver, 2001; Leksakundilok, 2004). It also emphasizes on cultural exchange between natives and tourists (Saaty and Vargas, 2001; Mendoza and Prabhu, 2006).

Sustainable tourism entails thestudy oftourism activities and ecological capacities, as well as balancing the interest of stakeholders $(\mathrm{Ok}, 2006)$. The strategies for sustainable tourism development should be presented in the form of a management plan to minimize damages to the environment (Lindberg and Mckercher, 1997).

AHP method was developed by Saaty in 1980 as a tool for Multi Criteria Decision Making (MCDM) (Saaty, 1980). AHP is a useful method for identification and prioritization of criteria for various purposes (Mendoza and Prabhu, 2006; Sharpley, 2006). AHP has been used widely in different fields by researchers worldwide (Vaidya and Kumar, 2006). The purpose of MCDM methods is to help decision-makers solve complex decision-making issues (Vaidya and Kumar, 2006). MCDM includes the steps of identification, weighting, and prioritization of criteria (Malczewski, 2004).

GIS is a SDSS tool that has broadly been used in tourism studies (Babaie-Kafaky, 2009). GIS could facilitate preparing the maps of natural resources (Gul, 2006). it has been used for data processing in the different fields of geomorphologic and pedological studies, land evaluation, site selection, land use planning, etc. (Culbertson, 1994). 
Several criteria have been used for site selection of ecotourism destinations, including plant density, flora, fauna, plant biodiversity, fragile habitats, water quality, wildlife species, land cover, and many others (Boyd et al.,1995; Bunruamkaew and Murayam ,2011). Boyd et al. (1995) reported that environmental characteristics, income, responsibility, and socioeconomic property are of important criteria for ecotourism development. Boyd and Butler in 1993 studied ecotourism potentials of Northern Ontarian using the criteria of cultural characteristics, landscape, wildlife species, natural resources, and local communities (Boyd and Butler, 1993). OK in 2006 developed a MCDM model based on ELECTRE method, consisting of 28 alternatives and a total number of 19 criteria (e.g. horse-riding, shooting, and sportive fishing) for ecotourism management in Uganda. Kumari et al. (2010) combined five indices including Wildlife Distribution Index (WDI), Ecological Value Index (EVI), Ecotourism Attractively Index (EAI), Environmental Resiliency Index (ERI), and Ecotourism Diversity Index (EDI) to identify and prioritize the potential ecotourism sites in the West District of Sikkim state, India.

The present study was conducted to develop a simple SDSS model based on AHP, Fuzzy, and GIS for optimized ecotourism site selection in the Caspian Hyrcanian Mixed Forests ecoregion.

\section{METHODS AND MATERIALS}

\subsection{Study Area}

Anzali is the most important and environmentally sensitive watershed in northern Iran situated between the longitudes $48^{\circ} 45^{\prime}-49^{\circ} 42^{\prime} \mathrm{E}$ and the latitudes $36^{\circ} 55^{\prime}-37^{\circ} 32^{\prime} \mathrm{N}$ (Figure 1 ), over an area of $1800 \mathrm{~km}^{2}$ (Jica, 2005). As a part of the Caspian Hyrcanian Mixed Forests ecoregion, the watershed is of popular tourist destinations in Iran. Maximum and minimum heights are found at the altitude of $3100 \mathrm{~m}$ in the south and $-28 \mathrm{~m}$ in northern coast of the Caspian Sea. It is divided by two main landforms; a flat area; low-lying plain in the north, and a mountainous area in the south. The plain, with altitude height of less than $100 \mathrm{~m}$, is mainly covered by paddy fields and orchards (Jica, 2005). Anzali has been registered as an international wetland in the 1975 Ramsar Convention. It provides habitats for migrating birds. The climatic condition of the watershed is humid to very humid, with an annual rainfall of approximately between $400 \mathrm{~mm}$ and $2000 \mathrm{~mm}$ and a tempering temperature ranging from $0.8^{\circ} \mathrm{C}$ to $37^{\circ} \mathrm{C} ; 17^{\circ} \mathrm{C}$ on an annual average (Jica, 2012). The soils of the watershed are of two types "mountainous soils" and "plain soils". The mountainous soils covered by entisols and cambisoil containing mollic and ochric (buried) epipedons while plain soils are of gleysols and gleyicluvisols types. 


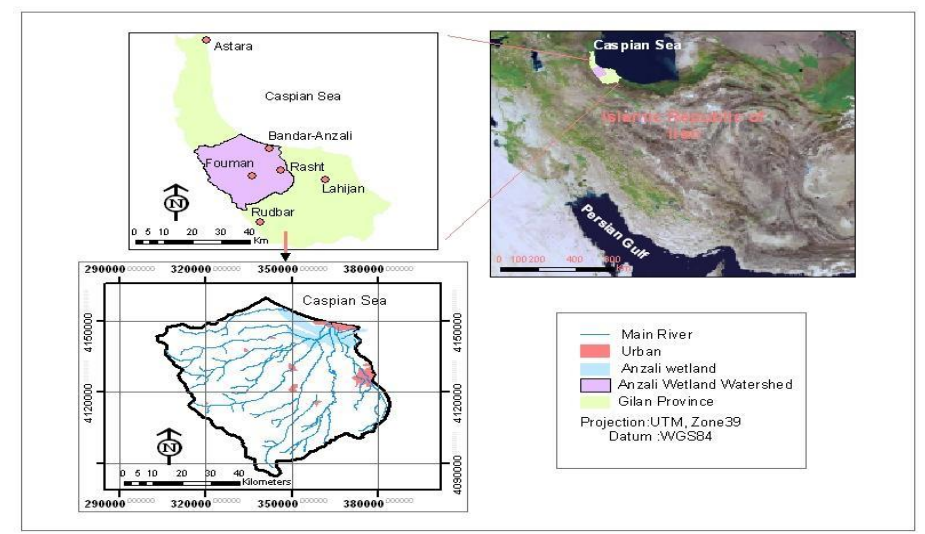

Figure 1: Location of Anzali Watershed in Gilan Province and in Iran.

\subsection{Research Procedure}

\subsubsection{Data Collection}

In this research, data were collected using field surveys, questionnaires, and literature reviews (Table 1). As an initial step, an inventory of criteria affecting ecotourism development in the study area was prepared. The questionnaires were placed at the disposal of Delphi panelists. The panelists were experts with at least five years of relevant experience in the field of tourism affairs. At the first round of Delphi, the questionnaires were distributed among a total number of 20 respondents. They were asked to score the criteria using a five-point Likert scale. Excluding less-important criteria, the former list was shortlisted. Consensus on the importance of criteria was achieved at the third round. After identification of site selection criteria, the relevant map layers were prepared using Arc GIS 10.1 and Global Positioning System (GPS). Criteria are of two types; factors and constraints. A factor is a criterion that enhances up or detracts from the suitability of a specific alternative for a considered activity. A constraint serves to limit the alternatives and classify the areas into two classes of unsuitable (value 0) or suitable (value 1) (Boolean Logic) (Zaredar et al., 2010). All map layers were transferred into the same coordinate system of UTM, zone39N.

Table 1: List and sources of data collected.

\begin{tabular}{c|c|c}
\hline Data & Scale & Source \\
\hline Anzali wetland & $1: 25000$ & Department of Environment \\
\hline Land use/ Cover map, 20 & $1: 50000$ & Satellites Images \\
\hline DEM & $1: 25000$ & National Cartographic Center \\
\hline Tourist map & $1: 50000$ & $\begin{array}{c}\text { Cultural Heritage, Handcrafts and Tourism } \\
\text { Organization }\end{array}$ \\
\hline Protected areas & $1: 25000$ & Department of Environment \\
\hline Roads and infrastructure & $1: 25000$ & Minister of Road and Urban Development \\
\hline Water resources & $1: 25000$ & Ministry of Power \\
\hline Geology/fault/landslide & $1: 100000$ & Organization of Geology
\end{tabular}




\subsubsection{AHP Method}

AHP is one of the commonly-used MCDM techniques (Saaty, 1980; Saaty and Vargas, 2001). It is used to formalize decision-making problems when there are a limited number of choices available, each of which with several attributes. AHP is a method to derive ratio scales from pair-wise comparisons (Saaty, 1980). Selecting appropriate criteria is a crucial task in MCE (Saaty and Vargas, 2001). In this research, MCE criteria were selected by literature reviews, field studies, and questionnaires. Selected criteria were weighted using pair wise ranking method developed by Saaty in 1980. In this research, Delphi panelists were asked to give priority to the shortlisted criteria using a 9-pint weighting scale presented by Saaty (Table 2). The scale values vary from 1 that indicates equal preference of criteria in the pair wise comparison matrix to 9 represented extremely preference of criteria in the pair wise comparison matrix. At final step, weighting accuracy was checked by Consistency Ratio (CR). The CR value less than 0.1confirms accuracy of given weights otherwise weighting process must be repeated (Saaty, 1980).

In this research, the expert panelists were polled twice; once for short-listing of the initial inventory of ecotourism criteria, and again for weighting and prioritizing of the shortlisted criteria.

Table 2: A nine-point scale for pairwise comparisons, AHP Method.

\begin{tabular}{c|c}
\hline Scale & Degree of preference \\
\hline 1 & Equal importance \\
\hline 3 & Moderate importance \\
\hline 5 & Strong importance \\
\hline 7 & Very strong importance \\
\hline 9 & Extreme importance \\
\hline $2,4,6$ and 8 & Intermediate values \\
\hline
\end{tabular}

\subsubsection{Preparation of Map Layers}

According to the panelists, "soil", "distance from water resources", "land use", "distance from residential areas", "slope", "distance from roads", "land cover density", "erosion", "climate", and "aspect" were recognized as the most important criteria affecting ecotourism development in the study area. The slope map was prepared from topographic map. The aspect map was derived from Digital Elevation Model (DEM) with a pixel size of $25 \mathrm{~m}$. The climatic data were obtained from Metrological Organization of Iran. As important factors on health and safety of tourists, the maps of erosion, faults, and flood zones were prepared from Iranian Organization of Geology. Soil types, which play a critical role in land suitability for ecotourism development, were categorized based on the classification presented by FAO (FAO, 1974). Land use map of the watershed was prepared from IRS satellite images dating back to 2007 on which, different land uses of farmlands, wetlands, woodland, coastal areas, and fragile ecosystems such as wildlife corridors and habitats were specified. It is worth mentioning that highly dense forest or rangeland areas were considered as constraints and excluded from candidate areas for ecotourism development. These areas were dedicated to nature protection. "Distance from roads" and "distance from water resources" were considered as two economic criteria for ecotourism development in the study area. 


\subsubsection{Running of SDSS Model}

Map layers are expressed in various measuring scale e.g. slope map in percent (\%), elevation map in meter $(\mathrm{m})$. Thereby, in order to compare criteria maps with each other, all values should be standardized and transformed into the same measurement unit (Kheirkhah Zarkesh et al. 2010). In this research, the map layers were standardized using fuzzy logic based on a value set of between 0 and 1 or 0 and 255 and as well as membership functions (Equations 1 and 2).

$$
x_{I}=\frac{\left(R-R_{\min }\right)}{\left(R_{\max }-R_{\min }\right)} * 255
$$

Where;

$\mathrm{Xi}=$ dimensionless value in a positive or increasing state (in 0-255 range)

$\mathrm{R}=$ initial value

$\mathrm{R}$ max $=$ maximum value

$\mathrm{R}$ min $=$ minimum value

$$
X_{I}=\frac{\left(R_{\max }-R\right)}{\left(R_{\max }-R_{\min }\right)} * 255
$$

$\mathrm{Xi}=$ dimensionless value in a negative or decreasing state (in 0-255 range)

After the standardization step, AHP method was used to weight and rank the ecotourism criteria using IDRISI software (Saaty and Vargas, 2001; Malczewski, 2004). Simultaneously, consistency ratio of weights was check to ensure that all of the judgments are consistent. At final step, the weighted map layers were overlaid using Weighed Linear Combination (WLC) method in order to determine suitable areas for ecotourism development in the study area.

Table 3: Upper and lower constraint values of ecotourism criteria.

\begin{tabular}{c|c}
\hline \multirow{4}{*}{ Factors } & Criteria definition \\
\hline \multirow{4}{*}{ Aspect } & Favorable: Flat, east in summer, south in winter \\
\cline { 2 - 2 } & Intermediate: north in summer, west in winter \\
\cline { 2 - 2 } Climate (temperature) & $\begin{array}{c}\text { Unfavorable: south and west in summer and spring, } \\
\text { east and north in winter }\end{array}$ \\
\cline { 2 - 2 } & Favorable: ${ }^{\circ} 5-25^{\circ}$ \\
\cline { 2 - 2 } Erosion & Intermediate: $25^{\circ}-37^{\circ}$ \\
\cline { 2 - 2 } & Unfavorable: $<5^{\circ}$ and $>37^{\circ}$ \\
\cline { 2 - 2 } & Favorable: little \\
\hline \multirow{3}{*}{ Land cover density } & Intermediate : low, moderate \\
\cline { 2 - 2 } & Unfavorable: high , very high \\
\cline { 2 - 2 } Slope & Favorable: $40-70 \%$ \\
\hline \multirow{3}{*}{ Intermediate $: 0-40 \%$} \\
\cline { 2 - 2 } & Unfavorable: $<40 \%$ \\
\cline { 2 - 2 } & Favorable: $0-10 \%$ \\
\hline \multirow{2}{*}{ Distance from roads } & Intermediate : $10-45 \%$ \\
\cline { 2 - 2 } & Unfavorable: $>45 \%$ \\
\hline
\end{tabular}

Bol. Ciênc. Geod., sec. Artigos, Curitiba, v. 21, no 2, p.340-353, abr-jun, 2015. 


\begin{tabular}{|c|c|}
\hline & Unfavorable: $<76 \mathrm{~m}$ and $>1000 \mathrm{~m}$ \\
\hline \multirow{3}{*}{$\begin{array}{l}\text { Distance from water } \\
\text { resources }\end{array}$} & Favorable: $50-500 \mathrm{~m}$ \\
\hline & Intermediate $: 500-1000 \mathrm{~m}$ \\
\hline & Unfavorable: $0-50 \mathrm{~m}$ and $>1000 \mathrm{~m}$ \\
\hline \multirow{3}{*}{ Land use } & Favorable: parts of Anzali Wetland, forest and coastal areas \\
\hline & Intermediate : others, except unfavorable \\
\hline & $\begin{array}{l}\text { Unfavorable: irrigated farming, urban areas,landslide, } \\
\text { fragile ecosystems and flood zones }\end{array}$ \\
\hline \multirow{3}{*}{ Soil (Texture) } & Favorable: loamy \\
\hline & Intermediate : sandy-loam, loamy-sandy \\
\hline & Unfavorable: heavy \\
\hline \multirow{3}{*}{$\begin{array}{l}\text { Distance from } \\
\text { residential aras }\end{array}$} & Favorable:500 -5000 m \\
\hline & Intermediate :500- $2000 \mathrm{~m}$ \\
\hline & Unfavorable: residential areas a height of $>5000 \mathrm{~m}$ \\
\hline
\end{tabular}

$\sum w_{i} x_{i} \Pi c_{j=} \mathrm{S}(3)$

Where, $\mathrm{S}=$ suitability degree; $w_{\mathrm{i}}=$ the weight of the factor $I ; x_{i}=$ dimensionless value of the factor $I$; $c_{j}=$ constraint map; $\Pi=$ multiply mark.

Research procedure is depicted in Figure 2.

Figure 2: Research procedure.

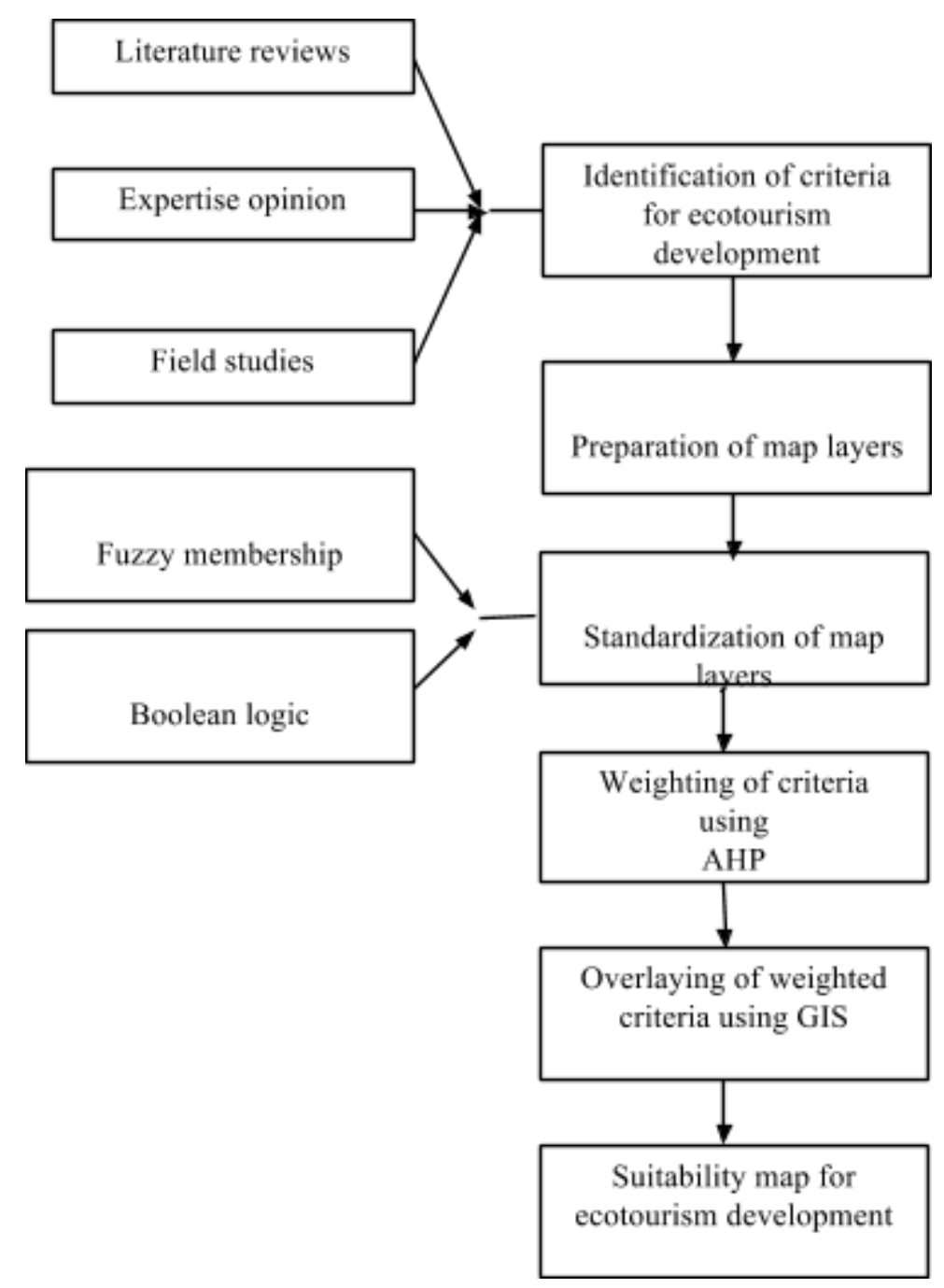

Bol. Ciênc. Geod., sec. Artigos, Curitiba, v. 21, nº 2, p.340-353, abr-jun, 2015. 


\section{RESULTS AND DISCUSSION}

Figure 3 shows distribution of different land uses in Anzali Watershed. As the figure demonstrates, irrigated farming, woodlands, and Anzali Wetland cover 143836ha (40\%), 137310ha (38\%), and13647ha (4\%) of the total study area, respectively.

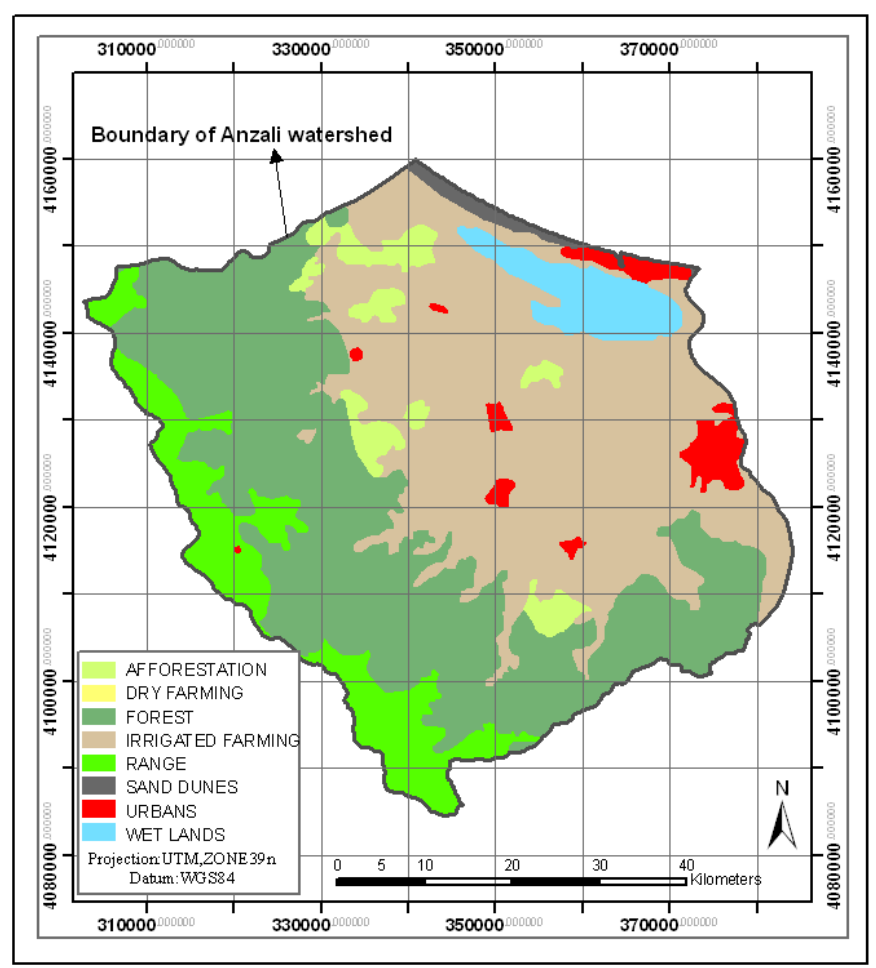

Figure 3: Different land uses in Anzali Wetland.

In this research, landslides, faults, fragile ecosystems, flood zones, irrigated fields, steep areas with a slope of more than $45 \%$, land cover with a density of higher than $70 \%$ were considered as a constrain map and excluded from the study area (Figure 4). These areas are not suitable for ecotourism development.

Figure 5 illustrates the weights of different criteria given by AHP Method. The consistency ratio was 0.09 , which confirms accuracy of the weightings. The obtained results indicated that the highest weights were assigned to the criteria "distance from water resources", "land use", "slope", and "soil" in a descending order while the lowest weights were given to the criteria "distance from residential areas", and "aspect", respectively. 


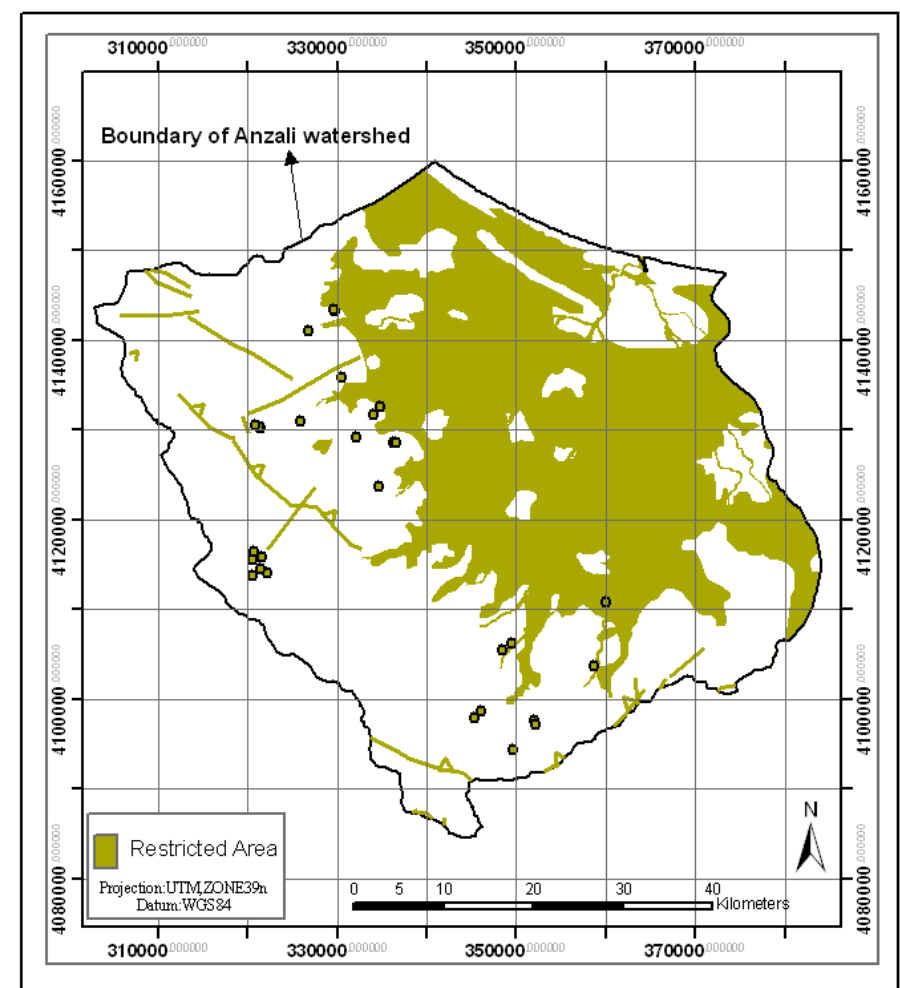

Figure 4: constrain map layers for ecotourism development in Anzali Watershed.

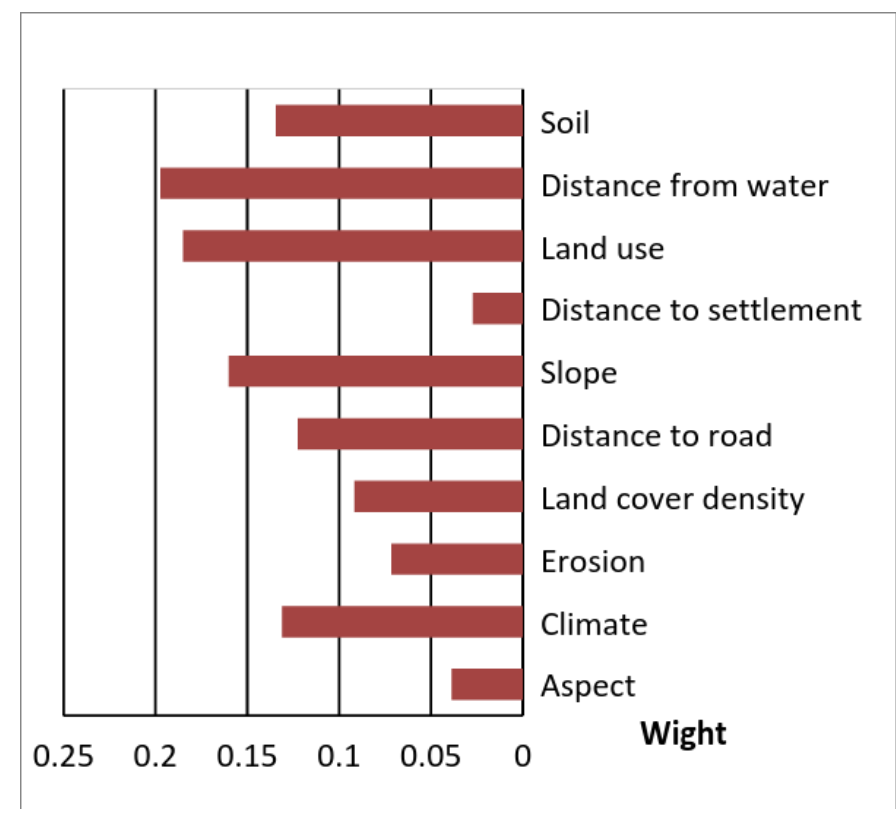

Figure 5: Weighting and prioritization of ecotourism criteria.

In arid and semi-arid areas such as Iran, water resources play a determining role in tourist destinations. Tourists prefer to spend their leisure time somewhere that possibly has the closest distance from water sources such as springs, rivers, wetlands, lakes, etc. Whatever a tourist destination is closer to water resources; it would have a greater potential for ecotourism development. Land use types would be in conflict or in line with tourist activities. As such, forest land use is of appealing land uses for ecotourism development while 
farmlands are not commensurate with ecotourism. Soil features can greatly affect tourist activities in tourist destinations so that marsh soils severely limit recreational activities or walking on loosely structured soils can cause severe erosion. Slope factor can be considered as a very basic parameter in land evaluation for ecotourism development. Tourism activities in steep areas would lead to extensive land degradation. Also, the aspect factor, due to its influence on climatic conditions e.g. number of sunny/frost days, has a role in tourists' comfort. Ecotourism that relies on natural attractions is totally incompatible with buildup areas. Accordingly, farther distances from population centers would have higher values for ecotourism development.

According to the obtained results, "slope" and "aspect" are of two important criteria for ecotourism development, of which "slope" is much more important. Although "aspect" was given less priority compared to other criteria, however, its important role in ecotourism development could not be neglected. The steep areas with a slope of more than $>45 \%$ are a limiting factor for ecotourism activities. Similar results were reported by Bunruamkaew and Murayam (2011) in Thailand and Gul et al. (2006) in Turkey. They concluded that "slope" would be an appropriate criterion for ecotourism development in areas with a slope of more than $15 \%$. "Aspect" was also another important factor for ecotourism site selection in Anzali Watershed so that eastern areas in summer time and southern slopes in winter season provide ideal conditions for ecotourism activities.

As the results suggest, climatic conditions in the watershed support ecotourism activities all year around; spring and summer are the best seasons for ecotourism activities. Similar results were reported by others researchers, e.g. Gul et al. (2006) in Turkey, and Kumari et al. (2010) in Malaysia. They also introduced number of "sunny days", and "frost days" as two other important criteria for ecotourism activities. However, in Anzali Watershed, temperature is usually above the freezing temperature.

The research findings revealed that woodland areas have unique potentials for ecotourism activities. Similarly, several studies have highlighted the importance of forests for ecotourism development. For instance, Anomasiri (2004), and Bunruamkaew and Murayam (2011) recognized forested areas as the most important zone for ecotourism development in Thailand. Similar results were reported for different climatic conditions such as Canada (Boyd and Butler, 1993), Malaysia (Amino, 2007), and Turkey (Gul et al., 2006).

In this study, "access to water resources" was given the highest weigh so that farther distance from water resources decreases suitability for ecotourism activities. The importance of "distance from water resources" was emphasized in several studies (Weaver, 2001; Gul, 2006; Kumari et al., 2010; Lindberg and Mckercher, 1997). "Distance from roads" is another important criterion for ecotourism development. It can facilitate easy access of tourists to destinations. This was highlighted by other researchers e.g. Boyd and Butler, 1993; Lindberg and Mckercher, 1997; Gul et al., 2006; Mendoza and Prabhu, and Kumari et al., 2010.

Anzali Watershed is mostly covered by coastal zones, woodlands, irrigated fields, orchards, and urban areas. In this research, irrigated farming, fragile ecosystems, land cover with a density of more than $70 \%$, wildlife corridors, urban areas, and orchards were considered as constraint zones as illustrated in Figure 6. 


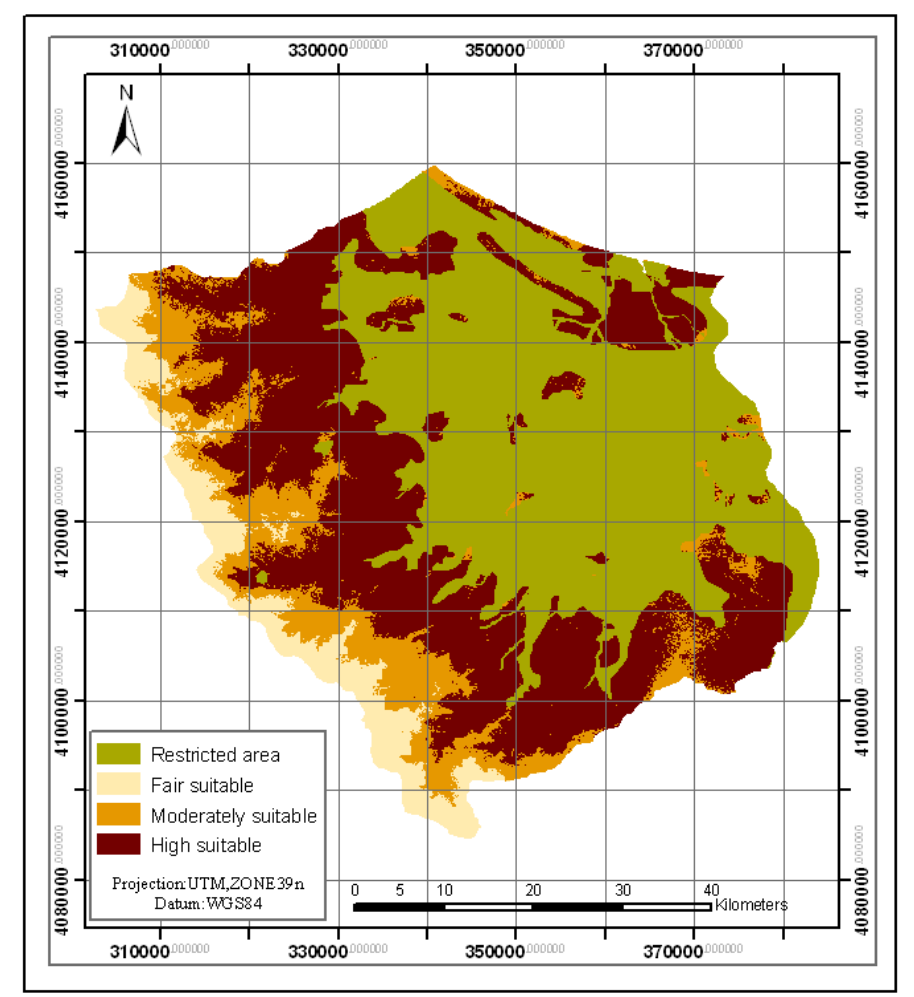

Figure 6: Land suitability for ecotourism development in Anzali Watershed.

According to the obtained results, the highest-ranking score was allocated to "distance from water resources", land use, and slope. Furthermore, special consideration was given to both "unique nature of Hyrcanian forest", and "Anzali Wetland" due to their diverse ecological conditions, which is suitable for ecotourism activities.

From altitudinal viewpoint, the watershed was divided into four categories of 0, 0-150 m,150$200 \mathrm{~m}$, and $>200 \mathrm{~m}$. Altitudes higher than $200 \mathrm{~m}$ (category 1) have high suitability for ecotourism activities while categories $2(150-200 \mathrm{~m})$ and $3(0-150 \mathrm{~m})$ have moderate and fair suitability for ecotourism development. Category 4 was recognized as a constraint factor for ecotourism development.

Suitability of Anzali Watershed for tourism development is presented in Figure 5.According to which, approximately $36.4 \%$ of the total study area equal to130978 ha (36.4\%) in southern watershed has high suitability for tourism development. These areas are covered mainly by forests and fragile ecosystems such as protected areas and wetlands. Accordingly, tourism activities in these areas must be done along with strict environmental considerations to avoid deterioration of the landscape. Areas with moderate suitability cover 12.8\% (46337 ha) of the study area. These areas are distributed almost all over the watershed. Moderately suitable areas include Hyrcanian forests at heights, a part of coastal zone in northern watershed, and plains. Poorly vegetated areas at high altitudes cover an area of over 26747 ha (7.4\%) in southern watershed, which have fair suitability for ecotourism activities. unsuitable areas for ecotourism development mainly include irrigated farmlands (paddy fields), landslide zone, residential areas, and land cover with a forest density of more than $70 \%$ stretched over an area of 156138 ha $(43.4 \%)$. 


\section{CONCLUSION}

This research presents a comprehensive approach integrating GIS, AHP, and MCE to identify suitable areas for sustainable ecotourism activities. The main advantages of this approach are weighting of criteria, flexibility, and capability of integrating with GIS. In this research, suitable criteria for ecotourism development were selected based upon expertise opinion, literature reviews, and field studies. It is worth mentioning that site selection criteria for ecotourism development vary in different regions depending on socio-economic and ecological conditions. In this research, land suitability for was performed using a total number of 10 criteria and 7 constraints, among which, "distance from water resources", "slope", and "land use" were top-three priority criteria. The research finding shows that the combination approach of WLC and GIS is a suitable tool for ecotourism land evaluation. This is the first time that this model is used for ecotourism devolvement of Anzali Watershed. Anzali Basin has a fragile ecosystem that requires careful planning for ecotourism development in a way to mitigate or possibly prevent deterioration of natural resources in tourist destinations. The results of the present study, by identification of suitable areas for ecotourism development, will help decision-makers to prepare an appropriate management plan restricting ecotourism activities only in places with high potentials for ecotourism development.

Fuzzy AHP is a powerful decision support system for site selection purposes. It can easily solve the issue of involving viewpoints of various stakeholders in priority setting and weighting process. By using Fuzzy AHP, site selection process will be done in the lowest possible time and cost. Providing mechanisms to control consistency of the evaluation and priority setting by Delphi panelists, it can resolve the problem of biased judgments. This is a unique capability that distinguishes it from other MCDM methods such as ELETRE, and TOPSIS. Further, Fuzzy AHP can provide the possibility of simultaneous involvement of qualitative and quantitative criteria in land evaluation studies.

\section{ACKNOWLEDGEMENT}

We would like to express our highest appreciation for the services rendered by Ravian Danesh Mohit Company in providing insightful comments and proofreading of the manuscript.

\section{REFERENCES}

Abidin, Z. Z.The identification of criteria and indicators for the sustainable management of ecotourism in Taman Negara National Park, Malaysia: A Delphi Consensus. Ph.D. Dissertation, West Virginia University, Morgantown, WV, USA, 1995.

Amino, M. A. Geographic information system (GIS) and multi-criteria analysis for sustainable tourism planning. Masters thesis, University Technology of Malaysia, 2007.

Anomasiri, W. Eastern philosophy of ecotourism management model in Mae Son Province, Thailand. Master Thesis, Technology of Environmental Management, Faculty of Graduate Studies, Mahidol University, Bangkok, Thailand, 2004. 
Babaie-Kafaky, S.; Mataji A.; Ahmadisani N. Ecological capability assessment for multipleuse in forest areas using GIS- based multiple criteria decision making approach. American Journal of Environmental Sciences,v.5, n.6, p. 714-721, 2009.

Boyd, S. W.; Butler, R. W.; Haider W. Identifying criteria and establishing parameter for forest-based ecotourism in Northern Ontario, Canada. Ressources naturelles Canada, Service canadien des forêts, 7 pages, 1995.

Boyd, S. W.; Butler, R. W. Review of the development of ecotourism with respect to identifying criteria for ecotourism for Northern Ontario. Department of Natural Resources/ Forestry, Ministry of Natural Resources. Sault Ste. Marie, Ontario, 1993.

Bunruamkaew, K.; Murayama, Y. Site suitability evaluation for ecotourism using GIS \& AHP: a case Study of SuratThani Province, Thailand.

Procedia - Social and Behavioral Sciences, v.21, p. 269-278, 2011.

Ceballos-Lascurain, H. Tourism, Ecotourism, and Protected Areas. IUCN Protected Areas Program, Gland, Switzerland and Cambridge, UK, 1996.

Culbertson, K.; Hershberger, B.; Jackson, S.; Mullen, S.; Olson, H. GIS a tool for regional planning in mountain regions: Case studies from Cana Brazil, Japan, and the USA. In: Price, M.F. \& Heywood, and D.I. (Eds.), Mountain environments and GIS. Taylor \& Francis, London, p. 99-118, 1994.

Dhammapitaka, P.; Payuto, P. A. Sustainable development (In Thai). $7^{\text {th }}$ printing. KomolKhimthong Foundation Publishing, Bangkok, 2000.

Eastman, J. R. IDRISI and Guide to GIS and Image Processing. Clark University, 2006.

FAO, Approaches to land classification, Soils Bulletin 22. FAO, Rome, 1974.

Gul, A. M.; Orucu, K.; Oznur, K. An approach for recreation suitability analysis to recreation planning in Golchuk Nature Park. Journal of Environmental Management, v.37, n.5, p.606-625, 2006.

Japan International Cooperation Agency (JICA). Report of Anzali wetland watershed master plan. Department of Environment, Iran, 2005.

Japan International Cooperation Agency (JICA). Report of Anzali wetland watershed master plan. Department of Environment, Iran, 2012.

Kheirkhah Zarkesh, M. M.; Ghoddusi, J.; Zaredar, N.; Soltani, M. J.; Jafari, S.; Ghadirpour, A. Application of Spatial Analytical Hierarchy Process model in land use planning. Journal of Food, Agriculture and Environment, v.8, n.2, p. 970-975, 2010.

Kiker, G. A.; Bridges, T. S.; Varghese, A.;Seager, T. P.; Linkov, I. Application of multi criteria decision analysis in environmental decision making. Integrated Environmental Assessment and Management, v.1, n.2, P.95-108, 2005.

Kumari, S.; Behera, M. D.; Tewari, H. R. Identification of potential ecotourism sites in West District, Sikkim using geospatial tools. Tropical Ecology, v.51, n.1, p.75-85, 2010.

Leksakundilok, A. Ecotourism and community-based ecotourism in the Mekong Region. Working paper series: working paper no.10, The Australian Mekong Resource Centre, University of Sydney, Sydney, 2004.

Lindberg, K.; Mckercher, B. Ecotourism: a critical overview. Pacific Tourism Review, v.1, n.1, p. 65-79, 1997. 
Malczewski, J. GIS-based land use suitability analysis: A critical overview. Progress in Planning, v.62, n.1, p. 3-65, 2004.

Mendoza, G.; Prabhu R. Participatory modeling and analysis for sustainable forest management: Overview of soft system dynamics models and applications. Forest Policy and Economics, v.9, n.2, p. 179-196, 2006.

Ok, K. Multiple criteria activity selection for ecotourism planning in igneada. Turkish. Journal of Agriculture and Forestry, v.30, p. 153-164, 2006.

Saaty, T. L. The Analytic Hierarchy Process, New York: McGraw-Hill, 1980.

Saaty, T. L.; Vargas L. G. Models, methods, concepts and applications of the analytic hierarchy process. International series in operations research and management sciences. Kluwer Academic Publisher, springer, p.333, 2001.

Sharpley, R. Ecotourism: a consumption perspective. Journal of Ecotourism, v.5, n.1-2, p. 722. 2006.

Vaidya, O. S.; Kumar S. Analytic hierarchy process: An overview of applications. European Journal of Operational Research, v.169, n.1, p. 1-29, 2006

Weaver, D. Ecotourism, Brisbane: John Wiley and Sons, 2001.

Zaredar N.; Kheirkhah Zarkesh, M. M.; Ghadirpour, A.;Jozi, S. A.; Jafari, S.International Conference on Chemistry and Chemical Engineering (ICCCE), Kyoto, Japan, 1-3 Aug. 2010.

(Recebido em maio de 2014. Aceito em outubro de 2014). 